\title{
The Influence of the Family Environment, Academic Atmosphere and Critical Thinking on Student Creativity Prospective Teachers of Economics in Padang City
}

\author{
Ricci Lonia ${ }^{1 *}$, Yulhendri ${ }^{2}$
}

\author{
1,2 Universitas Negeri Padang \\ *Corresponding author. Email: Riccilonia1@gmail.com
}

\begin{abstract}
The objectives of this study were to: 1) analyze the influence of the family environment on critical thinking of economic teacher candidates in the city of Padang; 2) analyze the influence of the academic atmosphere on critical thinking students of former economics teachers in the city of Padang; 3) analyze the influence of the family environment on the creativity of economic teacher candidates in the city of Padang; 4) analyze the influence of the academic atmosphere on the creativity of prospective economics teachers in the city of Padang; 5) analyze the effect of critical thinking on the creativity of economic teacher candidates in the city of Padang. The population in this study were students of economics teacher candidates in the city of Padang with a sample size of 300 respondents. Data obtained were analyzed using Structural Equation Modelling (SEM) with Smart PLS 3.0. The results showed that: 1) the family environment has a significant effect on critical thinking of economic teacher candidates in the city of Padang; 2) the academic atmosphere has a significant effect on the critical thinking of prospective economics teacher students in the city of Padang; 3) the family environment has a significant effect on the creativity of economic teacher candidates in the city of Padang; 4) the academic atmosphere has a significant effect on the creativity of prospective economics teachers in the city of Padang; 5) critical thinking has a significant effect on the creativity of economic teacher candidates in the city of Padang.
\end{abstract}

Keywords: Family environment, Academic atmosphere, Creativity critical thinking.

\section{INTRODUCTION}

Students must have creativity. Creativity and intellectuality are two important things in acquiring knowledge. Students are said to be creative if they are aware of their existence and want to make an innovation. Meanwhile, intellectual students are students who are critical in responding to and dealing with existing phenomena. Therefore, creative students are students who can take advantage of their own abilities and want to develop them so that they become creative new ideas and become the key to success.

According to [1] creativity symbolizes existence and immortality in the universe, and this existence is shown in its original form as mental and psychological wellbeing and productivity with the help of creative thinking. Meanwhile according to [2] Creativity has been considered a prevalent academic subject in several fields.

As prospective teachers, students are required to be creative. Because as a prospective teacher, students must be able to generate new ideas and new knowledge for their students. Likewise, with prospective economics teachers. If the student is creative, then the student will have a complete personality, have a fighting spirit so that he can solve existing problems.

The creativity of students can see that are with the Student Creativity Program (PKM). The following are PKM data for five fields that are followed by students in the city of Padang. 
Table 1. PKM data five fields attended by students in the city of Padang

\begin{tabular}{|c|c|c|c|c|c|c|}
\hline \multirow{2}{*}{ No } & \multirow{2}{*}{ Year } & \multicolumn{2}{|c|}{ College } & \multirow{2}{*}{$\begin{array}{c}\text { Number of Students in } \\
\text { Padang City }\end{array}$} & $\%$ \\
\cline { 3 - 5 } & & $\begin{array}{c}\text { Private } \\
\text { Collage }\end{array}$ & Public Universities & Total & 94,112 & $0.15 \%$ \\
\hline 1 & 2017 & 8 & 137 & 145 & 88,419 & $0.16 \%$ \\
\hline 2 & 2018 & 4 & 137 & 141 & 82,590 & $0.16 \%$ \\
\hline 3 & 2019 & 13 & 117 & 130 & 265,121 & $0.16 \%$ \\
\hline \multicolumn{2}{|c|}{ Total } & 25 & 391 & 416 & & \\
\hline
\end{tabular}

The table above shows the number of students in Padang City who participated in the Student Creativity Program (PKM) activities from 2017-2019. Seen in 2017, there were 8 students at private universities who participated in PKM activities and 137 students at State Universities with a total of 145 students who participated in PKM activities in 2017 with a percentage of $0.15 \%$. Whereas in 2018 there were 4 students at private universities who participated in PKM activities and 137 students at State Universities with a total of 141 students participating in PKM activities in 2018 with a percentage of $0.16 \%$. However, in 2019 there were 13 students at private universities who participated in PKM activities and 117 students at State Universities with a total of 130 students participating in PKM activities in 2019 with a percentage of $0.16 \%$.

From the table above, it can be interpreted that there is a lack of creativity in students in the city of Padang. This is evident from the low percentage figures found each year. Students who are creative must have a good level of intelligence, due to being a creative student in a field where they can create an innovation, which is in accordance with the goals of PKM itself, namely: innovative, creative, and cooperative.

[3] revealed that family environmental factors influence a person's creativity level. Individuals who are different around an environment with high creativity, then individuals will also be more creative too, and vice versa. With a conducive academic atmosphere, it will be able to help students in learning so as to support students to be more active so that it will increase creativity. However [4] said that the factor that influences creativity is critical thinking. This is proven by research conducted by [4] regarding creativity, whose research results show that there is a relationship between critical thinking and creativity.

Research conducted by [5] entitled "The role of motivation, parental support, and peer support in the academic success of ethnic minority first-generation college students". Where the research results say that support from parents is the most important thing for the development process of adolescents and adults which will later affect the academic results of these children including the level of critical thinking. According to [6] support from parents plays an important role in the development and thinking of children. In line with this study, parental support is one indicator of the family environment.

According to [6] one of the factors that influence creativity is the environment. [6] said that someone who tends to be in an active and good environment will increase one's creativity level. Along with research conducted [3] which revealed that family environmental factors affect a person's creativity level. Individuals who are different around the environment with high creativity will also be more creative, and vice versa.

According to research conducted [7] with the title "A Mixed-Methods Investigation of the Relationship between Critical Thinking and Library Anxiety among Undergraduate Students in their Information Search Process" said that one of the factors affecting critical thinking skills is the facility. library. According to [7], the completeness of the library greatly affects a person's level of critical thinking. So it can be concluded that the academic atmosphere affects a person's critical thinking skills. Because library facilities are an indicator of the academic atmosphere. The more complete the library facilities, the more it will help someone in finding information so that it can trigger someone's critical thinking.

According to research conducted by [8] with the title "Ascending Bloom's pyramid: Fostering student creativity and innovation in academic library spaces" there is one factor that influences creativity, where the results show that there is a relationship between library facilities and creativity. [8] said that spatial design in the library will encourage creativity and innovation in students. [8] believe that to continue to be a value for students and in line with universities, academic libraries must provide spaces that encourage creativity. So it can be concluded that the academic atmosphere affects one's creativity. Because library facilities are an indicator of the academic atmosphere.

According to research conducted by [4], with the research title "Thinking Skills and Creativity". There is one factor that affects creativity, where the results of the research show that there is a relationship between critical thinking and creativity. Along with research conducted by [9] with his research title "Critical 
thinking and creativity: An overview and comparison of the theories" suggests that there is a positive relationship between critical thinking and creativity. To be a creative person requires critical thinking.

H1: The family environment affects the critical thinking of prospective economics teacher students in the city of Padang.

$\mathrm{H} 2$ : The academic atmosphere affects the critical thinking of prospective economics teacher students in the city of Padang.

H3: The family environment affects the creativity of prospective economics teacher students in the city of Padang.

H4: The academic atmosphere affects the creativity of prospective economics teacher students in the city of Padang.

H5: Critical thinking affects the creativity of prospective economics teacher students in the city of Padang

\section{METHOD}

\subsection{Population and sample}

According to [10] population is a generalization area consisting of objects or subjects that have certain qualities and characteristics that have been determined by researchers to be studied and after that conclusions are drawn. The population in this study were students of economics teacher candidates in the city of Padang with a total sample of 300 economics teacher candidates in the city of Padang.

\subsection{Operational Definition Variable}

Creativity is a person's ability to find new ideas, formulate concepts that are not just memorizing so that they can create new things and new questions that can be answered and solved. Family environment is everything that is inside and outside the individual that can affect a person's behavior. Academic atmosphere is a nuance and everything in an academic environment that supports the creation of a conducive situation for students in tertiary institutions. Critical thinking is the ability to think someone who uses reasoning, reflective and responsible thinking. Someone who is critical will be careful in taking information and decisions using reasoning so that the conclusions can be accounted for and can be trusted.

\section{RESULT AND DISCUSSION}

The outer model evaluation was conducted to test the validity and reliability of the data. The validity test consists of convergent validity, discriminant validity, while reliability is tested using composite reliability. The results shown in the table can be stated to have convergent validity because each indicator has met the requirements for the outer loading value> 0.50 [11].

Table 2. Average Variance Extracted (AVE)

\begin{tabular}{|l|c|}
\hline \multicolumn{1}{|c|}{ Variable } & $\begin{array}{c}\text { Average Variance Extracted } \\
\text { (AVE) }\end{array}$ \\
\hline Family environment & 0.915 \\
\hline Academic atmosphere & 0.903 \\
\hline Critical thinking & 0.855 \\
\hline Creativity & 0.619 \\
\hline
\end{tabular}

Table 2 shows that all variables have an AVE value greater than 0.5 [11]. Therefore it can be concluded that all variables in this study can explain an average of more than half of the variants of each indicator which have good convergent validity.

In table 3 it can be seen that the composite reliability and Cronbach's alpha for each construct exceeds 0.7 . If referring to the rule of thumb value composite reliability and Cronbach's alpha which each value should be more substantial than 0.7 (> 0.7) [11] then the data in table 3 is expressed already reliable.

Table 3. Cronbach's Alpha and Composite Reliability

\begin{tabular}{|l|l|l|}
\hline \multicolumn{1}{|c|}{ Variable } & $\begin{array}{c}\text { Cronbach's } \\
\text { Alpha }\end{array}$ & $\begin{array}{c}\text { Composit } \\
\mathbf{e} \\
\text { Reliabilit } \\
\mathbf{y}\end{array}$ \\
\hline Family Ward (X1) & 0.982 & 0.985 \\
\hline Academic Atmosphere (X2) & 0.985 & 0.987 \\
\hline Critical Thinking (X3) & 0.981 & 0.983 \\
\hline Creativity (Y) & 0.942 & 0.950 \\
\hline
\end{tabular}

The structural model testing is done first by looking at the R-square value which is the goodness-fit model test. The following is the R-square indigo table from this study.

Table 4. $R$-Square

\begin{tabular}{|l|c|}
\hline \multicolumn{1}{|c|}{ Variable } & R Square \\
\hline Critical thinking (X3) & 0.773 \\
\hline Creativity (Y) & 0.699 \\
\hline
\end{tabular}

Table 4 can be seen that the R-Square value of the critical thinking variable (X3) shows a number of 0.773. This shows that the family environment (X1) and the academic atmosphere (X2) contribute to critical thinking (X3) as much as $77.3 \%$. The rest is influenced by other variables outside of this research model. 
Table 5. Total indirect effects output

\begin{tabular}{|l|c|c|c|c|c|}
\hline \multicolumn{1}{|c|}{ Hypothesis } & $\begin{array}{c}\text { Original } \\
\text { Sample (O) }\end{array}$ & $\begin{array}{c}\text { Sample } \\
\text { Mean (M) }\end{array}$ & $\begin{array}{c}\text { Standard } \\
\text { Deviation } \\
\text { (STDEV) }\end{array}$ & $\begin{array}{c}\text { T Statistics (| O / } \\
\text { STDEV |) }\end{array}$ & $\begin{array}{c}\text { P Values } \\
\text { VTDE }\end{array}$ \\
\hline $\begin{array}{l}\text { Family Environment (X1) -> } \\
\text { Critical Thinking (X3) }\end{array}$ & 0.075 & 0.075 & 0.026 & 2,849 & 0.005 \\
\hline $\begin{array}{l}\text { Family Environment (X1) -> } \\
\text { Creativity (Y) }\end{array}$ & 0.093 & 0.089 & 0.034 & 37,026 & 0.000 \\
\hline $\begin{array}{l}\text { Academic atmosphere (X2) -> } \\
\text { Critical thinking (X3) }\end{array}$ & 0.873 & 0.872 & 0.024 & 5,291 & 0.000 \\
\hline $\begin{array}{l}\text { Academic atmosphere (X2) -> } \\
\text { Creativity (Y) }\end{array}$ & 0.515 & 0.506 & 0.097 & 3,492 & 0.001 \\
\hline $\begin{array}{l}\text { Critical thinking (X3) -> } \\
\text { Creativity (Y) }\end{array}$ & 0.334 & 0.345 & 0.096 & \\
\hline
\end{tabular}

Table 5 is the result of the relationship between constructs which states that the family environment (X1) affects critical thinking (X3) with a parameter coefficient of 0.075 and significant at 0.05 ( $\mathrm{P}$ Values, 0.005). This can also be proven by looking at the $T$ statistic of 2.849 which has a value greater than the $\mathrm{T}$ table ( $\mathrm{T}$ count $2.849>\mathrm{T}$ table 1.96). Thus, hypothesis 1 (one) in this study is accepted .

While the results of the relationship between the constructs of the family environment (X 1 ) have an effect on creativity (Y) with a parameter coefficient of 0.093 and significant at 0.05 ( $\mathrm{P}$ Values, 0.006). This can be proven by looking at the $\mathrm{T}$ statistic of 6.161 which has a value greater than $\mathrm{T}$ table ( $\mathrm{T}$ count 2.740 > T table 1.96). Thus, hypothesis 2 (two) in this study is accepted .

Then the results of the relationship between the constructs of academic atmosphere (X 2 ) affect critical thinking (X 3 ) with a parameter coefficient of 0.873 and significant at 0.05 ( P Values, 0.000). This can be proven by looking at the T statistic of 37,026 which has a value greater than $\mathrm{T}$ table ( $\mathrm{T}$ count, 37,026> $\mathrm{T}$ table 1.96). Then hypothesis 3 (three) in this study is accepted.

Furthermore, it can be seen that the academic atmosphere variable (X 2 ) has an effect on creativity (Y) with a parameter coefficient of 0.515 and significant at 0.05 ( $\mathrm{P}$ Values, 0.000). This can be proven by looking at the $\mathrm{T}$ statistic of 5,291 which has a value greater than $\mathrm{T}$ table ( $\mathrm{T}$ count, 5,291> $\mathrm{T}$ table 1.96). Then hypothesis 4 (four) in this study is accepted .

Then the critical thinking variable (X 3 ) has an effect on creativity (Y) with a parameter coefficient of 0.334 and significant at 0.05 ( $\mathrm{P}$ Values, 0.001). This can be proven by looking at the $\mathrm{T}$ statistic of 3.492 which has a value greater than $\mathrm{T}$ table ( $\mathrm{T}$ count, 3.492> $\mathrm{T}$ table 1.96). Then hypothesis 5 (five) in this study is accepted .

\section{CONCLUSION}

Family environment significant effect on critical thinking student teachers in the city economy Padang. the variable Family environment against critical thinking is positive. This means that the better the family environment, the more critical thinking skills will be in students of economics teacher candidates in the city of Padang .

The academic atmosphere has a significant effect on the critical thinking of prospective economics teacher students in the city of Padang. the variab el academic atmosphere of critical thinking is positive. This means that the better the academic atmosphere of the students, the higher the level of critical thinking of prospective economics teacher students in Padang City.

Family environment has a significant effect on creativity in students of economics teacher candidates in the city of Padang. the family environment variables to $\mathrm{k}$ reativitas is positive. This means that students who are in a good family environment will further increase the creativity of prospective economics teacher students in the city of Padang.

The academic atmosphere has a significant effect on the creativity of students of economics teacher candidates in the city of Padang the variab el academic atmosphere of the Creativity is positive. This means that the higher the academic atmosphere of the students, the higher the creativity of students who are prospective economics teachers in Padang City.

Critical thinking affects creativity in students of economics teacher candidates in the city of Padang. The form of the influence of the Critical Thinking variable on Creativity is positive. This means that the higher the level of critical thinking of students, the higher the creativity of prospective economics teacher students in Padang City. 


\section{ACKNOWLEDGMENTS}

Thank you to Mr. Dr. Yulhendri, M.Si who has guided from start to finish until the completion of this article. Thank you to the Padang State University for providing knowledge and experience. Thank you to the family who have provided moral and material support. And thanks to friends for helpful help in making this article well written.

\section{REFERENCES}

[1] A.E. Aslan, \& G.J. Puccio, Developing and testing a Turkish version of Torrance's tests of creative thinking: A study of adults. Journal of Creative Behavior, 40 (3), 2006, pp. 163-177. https://doi.org/10.1002/j.2162-

6057.2006.tb01271.x

[2] E. Corakli, \& D. Batibay, The Efficacy of a Music Education Programme Focused on Creative Thinking. Procedia - Social and Behavioral Sciences, 46 (2011), 2012, 3571-3576. https://doi.org/10.1016/j.sbspro.2012.06.107

[3] L. Deng, L. Wang, \& Y. Zhao, How Creativity Was Affected by Environmental Factors and Individual Characteristics: A Cross-cultural Comparison Perspective. Creativity Research Journal, 28(3), 2016, 357-366. https://doi.org/10.1080/10400419.2016.1195615

[4] S.M. Wechsler, C. Saiz, S.F. Rivas, C.M.M Vendramini, L.S. Almeida, M.C. Mundim, \& A. Franco, Creative and critical thinking: Independent or overlapping components? Thinking Skills and Creativity, 27 (November 2017), 2018, 114-122. https://doi.org/10.1016/j.tsc.2017.12.003

[5] J.M. Dennis, J.S. Phinney, \& L.I. Chuateco, The role of motivation, parental support, and peer support in the academic success of ethnic minority first-generation college students. Journal of College Student Development, 46(3), 2005, pp. 223-236. https://doi.org/10.1353/csd.2005.0023

[6] E. Walsh, K. Anders, \& S. Hancock, Understanding, attitude and environment. International Journal for Researcher Development, 4(1), 2013, pp.19-38. https://doi.org/10.1108/ijrd09-2012-0028.

[7] N. Kwon, A mixed-methods investigation of the relationship between critical thinking and library anxiety among undergraduate students in their information search process. College and Research Libraries, 69(2), 2008, pp. 117-131. https://doi.org/10.5860/crl.69.2.117
[8] M. Bieraugel, \& S. Neill, Ascending bloom's pyramid: Fostering student creativity and innovation in academic library spaces. College and Research Libraries, 78(1), 2017, pp. 35-52. https://doi.org/10.5860/crl.78.1.35

[9] J. Marrapodi, Critical thinking and creativity an overview and comparison of the theories. Journal of Chemical Information and Modeling, 53(401), 1989, p. 160.

[10] Sugiyono, Cara Mudah Menyusun Skripsi, Tesis, Dan Dosertasi. Yogyakarta:. Alfabeta, 2013

[11] I. Ghozali,. Structural Equation Modeling metode alternatif dengan partial least square (PLS) (edisi 2). Semarang: Badan Penerbit Universitas Diponegoro, 2008. 